\title{
The relationship between pre-school children's patterning skills and language development
}

\author{
Yıldız Güven, Maltepe Universty, Turkey, yildizguven@maltepe.edu.tr, ORCID: 0000-0002-5120-7381 \\ Beyza Hamamci, Istanbul University-Cerrahpaşa, Turkey, beyzahamamci@istanbul.edu.tr, ORCID:0000- \\ 0001-9926-4345
}

Kübra Yayla, Marmara University, Turkey, kubrayayla@marun.edu.tr, ORCID: 0000-0001-9592-8466

\begin{abstract}
The aim of this study is to determine the relationship between preschool children's patterning skills and language development. 67 children (39 girls and 28 boys) of 58-77-month-old ( $\bar{x}=67.37$; $\mathrm{SD}=4.39$ ), attending pre-school education have participated in the study. The correlational research model was used to measure the two variables specified for the study and to determine the correlation between them. Preschool Patterning Skills Test was used to measure children's patterning skills and LAP3 Development Assessment Scale/Language Development Sub-Dimension was used to measure their language development. As a result of the analysis, it was found that children's patterning skills and language development did not differ according to the gender, but a significant difference was observed according to the education of their parents, in favor of those whose parents have an associate degree or above. Patterning skills and language development were observed to differ positively in favor of 68-77month-old children and those who perform more than one activity per week. Spearman correlation analysis revealed a positive and significant relationship between children's patterning skills and language development.
\end{abstract}

Keywords: Patterning skills, language development, pre-school education Received: $13.11 .2020 \quad$ Accepted: $16.12 .2020 \quad$ Published: 14.01.2021

\section{INTRODUCTION}

Recently, there has been an increase in studies on the importance of language skills for children's mathematical development (Donlan, Cowan, Newton, \& Lloyd, 2007; Gelman, \& Butterworth, 2005; Purpura, \& Ganley, 2014; Vukovic, \& Lesaux, 2013). Language is regarded to be related to conceptual thinking because of the words and word combinations, and to mathematics because of the symbols and symbol combinations (Nelson, 1996; Vinner, 2014). The results of various studies point the relationship between language and mathematical cognition (Donlan et al., 2007) and the effect of language on the process of learning mathematical concepts (Rittle-Johnson, Singer, \& Alibali, 2001). Besides, researchers underline that early number and language skills are related to each other and affect each other, just like other cognitive skills (Dehaene, Piazza, Pinel, \& Cohen, 2003; Gelman, \& Buterworth, 2005). This fact creates curiosity about the relationship between mathematics skills and language development of the children in the preschool period, which is seen as a critical period in their development process.

Mathematics and Patterning skills

Early childhood, which includes the preschool years, is an advantageous period for introducing young children to more formal mathematical operations, as they spontaneously show interest and competence in mathematics (Green, \& Gallagher, 2014). Children begin to learn mathematics by observing their surrounding (Tirosh, Tsamir, Barkai, \& Levenson, 2018). In early childhood, numbers, measurement, geometry, spatial and algebraic thinking are the areas of mathematics education (NCCA, 2014). Mathematical skills gain meaning through the processes such as counting, distinguishing, matching, classifying, sequencing, and patterning (Charlesworth, \& Lind, 2007; Dinçer, \& Ergül, 2017; Güven, 2005). In mathematics, children's understanding goes beyond simple concepts related to nu mbers (NCTM, 2006; Papic, Mulligan, \& Mitchelmore, 2011). Mathematics is also seen as the science of sequencing and patterning; it doesn't only express the numbers and the operations made with numbers (Steen, 1988; Resnik, 1982; Yaman, 2010).

Patterning is the skill of recognizing and using a predictable sequence (Rittle-Johnson, Zippert, \& Boice, 2018). In other words, a pattern is a component of the symbols, sounds, states or geometric shapes in units (Papic, Mulligan, \& Mitchelmore, 2011). Patterning, on the other hand, involves understanding how the sequencing rules of a series are applied to the elements of the other series following it (Burgoyne, Witteveen, Tolan, Malone, \& Hulme 2017). There are many mathematical relationships and 
patterns both in our daily life and in nature (Yaman, \& Umay, 2013). For example, seasonal cycles, repetition of the days of the week, the route that the school bus takes from school to home-home to school every day are the experiences involving patterns. Realizing the relationships in the patterns and generalizing these relationships will contribute to the development of children's ability to understand the world around them (Özdemir, 2013). In addition, patterning activities provide benefit to the development of skills such as basic numerical processing and sequencing, and the development of cognitive abilities such as reasoning and communication (Papic, \& Mulligan, 2005; Warren, \& Cooper, 2006). Including predictable patterning skills in early stages without any knowledge of numbers is suggested to constitute a basis for algebraic thinking in the future (Haciibrahimoğlu, 2015; Papic, Mulligan, \& Mitchelmore, 2011). Studies show that young children can understand patterns (Rittle-Johnson, Fyfe, McLean, \& McEldoon, 2013).

There are different types of patterning skills such as repeating, converting, finding the missing part, extension and growing (Copley, 2000; Güven, 2005; Güven, Dibek, Bayındır, \& Saçkes, 2019; Rittle Johnson, Fyfe, McLean, \& McEldoon, 2013; Yıldırım Haciibrahimoğlu, 2019). Preschool children first gain experience with repetitive patterns and then continue to work with patterns that can be extended and abstracted (Burgoyne, et al., 2017; Yeşildere, \& Akkoç, 2010). Studies cite the importance of solving more abstract patterns in relational reasoning, which is essential for cognitive development, and its contribution to learning mathematics in the future (Collins, \& Laski, 2015; Fyfe, McNeil, \& Rittle-Johnson, 2015). Many research results are showing the relationship between the patterns and mathematics skills (Lee, Ng, Bull, Pe, \& Ho, 2011; Lee, Ng, Pe, Ang, Hasshim, \& Bull, 2012). Many longitudinal studies also show that this relationship continues (Rittle-Johnson, Fyfe, Hofer, \& Farran, 2016; Vanderheyden, Broussard, Snyder, George, Meche Lafleur, \& Williams, 2011).

Language development

The term "language" is observed to have two meanings; the language used by humans and a symbolic system structure such as a programming language (Berwick, \& Chomsky, 2011). In humans, language consists of various sub-components such as phonology, syntax, morphology, semantics and pragmatics, and it is developed with the interaction of these components (Korkmaz, 2005). Phonology includes the systematic and functional features of the sound (Wiese, 2006). Syntax indicates the nature of the words and other structural units in a sentence, the relationship between the words and units in the sentence structure and the rules of sequencing them (İmer, Kocaman, \& Özsoy, 2011). Morphology is seen as the relationship between the form and meaning of the words, which includes the formation processes of word units and word forms (Bauer, 2006; İmer, Kocaman, \& Özsoy, 2011). Semantics refers to the meaning that the word conveys (Saeed, 2001), while pragmatics is explained as the use of language in social experiences (Mey, 2006). As you can see, language is a complex system in which many structures interact with each other.

In recent years, improvement has been made in understanding how the morphological properties of languages are acquired through the studies defining the biological, sociocultural, cognitive, and evolutionary mechanisms underlying language learning processes (Chater \& Christiansen, 2010; Christiansen, Chater, \& Reali, 2009; Christiansen, \& Chater, 2008). Language acquisition is the process of creating lexical categories such as nouns, adjectives, verbs, and functional categories such as subject, object, and verbs by dividing sound series into words, making generalizations and abstractions, and creating rules by combining them (Aksu Koç, \& Ketrez, 2016). From this point of view, language has a structure that includes pattern-like rules (Pinker, 1999; Sapir, 1925; Nettle, 1998). While learning the native language, the child learns the units of the language, the grammar of the language and the requirements of communicating with the language extemporarily (Yapıcl, 2004). Newborns are predisposed to acquire the sound systems of all languages, and basic phonological patterns are formed early in life before the formation of the words. In the following process, syntactic units such as the rhythm of the language and the syllable structure expand; the combination of the acquired words creates syntactic rules around the age of two, whereas the morphology is formed up to the age of four (Herschensohn, 2007). This information indicates that the basis of language skills is formed in the early childhood and that this period is critical in the development of individuals' language skills (Muslugüme, 2015; Herschensohn, 2007; Sandra, 2019). In the literature, language development is analyzed by being associated with different fields. The language development of preschool children is analyzed according to various variables, such as age, gender, parents' education level, number of siblings, birth order, and family income (Arslan, 2013; Başaran, 2006; Koçak, Ergin, \& Yalçın, 2014 ; Lovas, 2010; Stolt, Haataja, Lapinleium, \& Lehtonen, 2008; Taner, \& Başal, 2005; Yıldırım, 2008).

The Relationship between Patterning and Language Development

Language has an important role in the teaching and learning of mathematics (Austin, \& Howson, 1979). Adequate language skills have been suggested to be a prerequisite for learning early mathematics 
(Dehaene, Piazza, Pinel, \& Cohen, 2003) and a determinant of later mathematical performance (Purpura et al., 2011; Hooper, Roberts, Sideris, Burchinal, \& Zeisel, 2010). Besides, listening, speaking, reading and writing processes should be used to acquire a mathematical language (Grandau, 2015). Children use language to express their mathematical thoughts. As it is known, the words such as less, more, long, short, half, full, below, and above, which are used in mathematics, are extremely important in terms of learning and using mathematics. A mathematical language frequently used in mathematics is needed in learning numbers (such as counting numbers, decimals), learning arithmetic (such as addition, subtraction), problem solving (such as comparisons, increase, price), and learning mathematical concepts (such as pattern, measurement, geometry, space) (Purpura et al.2011; Toll., \& Van Luit, 2014). Teachers should be able to realize that children use mathematical concepts in their daily speech in preschool years and should transform the teaching moments into an advantage (Taşkın, 2013). Children with less verbal abilities exhibit lower mathematical knowledge (Hampden Thompson, Mulligan, Kinukawa, \& Halle, 2008; Klein, \& Starkey, 2004). Studies indicate that children's language skills can play a critical role in pattern abstraction. Patterns are at the center of all mathematical learnings and language learning (Fyfe, Evans, Matz, Hunt, \& Alibali, 2017). In addition, children with certain language disorders are at risk of experiencing difficulties in mathematical skills (Cowan, Donlan, Newton, \& Lloyd, 2005; Donlan, Cowan, Newton, \& Lloyd, 2007; Fazio, 1994). Fyfe, Eisenband Matz, Hunt, \& Alibali (2018) found that children with language development disorders have also difficulties in patterning skills. One reason for this is seen as the limitations in the interpretation of the auditory or visual inputs, which are in the form of consecutive patterns. For instance, when we hear a syllable, we predict the next syllable; which is associated with forming a simple pattern (sequence). On the other hand, researchers state that individuals' conversations by turns require organizational skills and point out the importance of patterning skills in this issue (Armstrong, 1983; Fine, 1978; Ravignani, 2014; Sacks, Schegloff, \& Jefferson, 1974; Welkowitz, Bond, Feldman. , \& Tota; 1990). Again, researches particularly mention the predictive effect of patterning on arithmetic and reading development (Burgoyne, Witteveen, Tolan, Malone., \& Hulme, 2017; Pasnak, Kidd, Gadzichowski, Gallington, Schmerold, Schmerold, \& West, 2015).

Regarding the studies in this field, the number of studies based on children's patterning skills and language development is found to be limited. Departing from this limitation, this study aims to examine the relationship between patterning skills and language development of 58-77-month-old children attending pre-school education institutions. In line with the purpose of the study, the following questions were addressed:

1- $\quad$ Do the scores of children attending pre-school education institutions got from the Patterning skills Scale and LAP-3 Development Assessment Scale/Language Development sub-dimension differ according to the gender, age group (58-67-month-old and 68-77-month-old), parents' education level and the frequency of patterning activities at school?

2- Is there a significant relationship between the scores that the children attending pre-school education institutions got from the Patterning Skills Scale and LAP-3 Development Evaluation Scale/Language Development sub-dimension?

\section{METHODS}

\section{Research Model}

This study was conducted according to the correlational research model, which is one of the quantitative research models. Being a type of descriptive research, the correlational model involves the examination of the relationship between two or more variables without any intervention (Büyüköztürk, Kllıç Çakmak, Akgün, Karadeniz, \& Demirel, 2017). In addition, in line with the sub-objectives of the research, children's patterning skills and language development were described and compared according to various variables.

\section{Study Group}

The study group of the study consists of 67 children (39 girls, 28 boys), aged between 58-77 months $(\bar{x}=67.37 ;$ sd $=4.39)$, who were studying in six classes of three preschool education institutions in Istanbul. $59 \%(\mathrm{n}=39)$ of the mothers of the children in the study group were graduated from high school or below and $41 \%(n=27)$ had an associate degree or above; whereas $42 \%(n=38)$ of the fathers were graduated from high school or below, and $48 \%(\mathrm{n}=27)$ had an associate degree or above. Education levels of one mother and two fathers are unknown. 


\section{Data Collection Tools}

Personal Information Form

Personal Information Form consists of five questions collecting demographic information about gender, date of birth, mother's education level, father's education level and the frequency of patterning activities at school. Personal information was obtained from the school administration before the administration of the study in pre-school educational institutions. Information on the frequency of patterning activities at school was obtained by interviewing teachers.

Preschool Patterning Skills Test - Short Form

Preschool Patterning Skills Test was developed by Güven, Dibek, Bayındır, \& Saçkes (2019) to measure the patterning skills of 61-76-month-old children. As a result of the validity and reliability analysis, two measurement tools were developed: the long form is comprised of 26 items, and the short form is comprised of 17 items. In this study, the short form of the measurement tool was used. Taking into consideration the content validity, a total of nine items were excluded from the scale and a 17-item form was created. Observations in the data collection process and the difficulty and overlap of the items in the Wright Map were taken into consideration in reducing the number of items. By considering the content validity, a total of nine items (E1, U1, D1, U2, E3, D3, US1, BB3, and 003) were excluded from the data set and the analysis was repeated. The results showed that all of the 17 items in the short form had INFIT and OUTFIT values of less than 2 MSNQ values. Item measure values ranged from -4.99 to 2.88 . The item separation index calculated for the short form was 4.90 and the person separation index was calculated as 1.65 . The person reliability coefficient was found to be 0.73 and the item reliability coefficient was found to be 0.96 . The reliability coefficient calculated by K-R20 was 0.81 . These results indicate that the scores obtained from the short form of the Pattern Test have an acceptable level of reliability. Coefficient of stability calculated for the short form was 0.84 .

LAP-3 Development Assessment Scale/Language Development Sub-Dimension: LAP - 3 Development Assessment Scale

It is a criterion-dependent scale developed by Anna R. Sanford et al. in 1969, titled as "The Learning Accomplishment Profile 3rd Edition (LAP-3)" and revised between 1981-2003; it is comprised a total of 383 items that allow the evaluation of the development of 36-72-month-old children. The original scale consists of seven sub-dimensions that were hierarchically prepared considering the chronological periods; gross motor skills (54 items), fine motor skills (40 items), preparation for literacy skills (38 items), cognitive skills (87 items), language skills (69 items), self-care skills (50 items) and personal/social development skills ( 45 items). Internal consistency coefficients of the original scale were between .96 to .99 for the whole scale, whereas they were found to vary between .78 and .97 (language development) for its sub-dimensions. The adaptation study of the scale into Turkish was done by Tunçeli (2018). In the adaptation study, the developmental areas of the original scale were preserved, and it was rearranged as a 256 item-scale evaluating the development of 42-72-month-old children. In the adaptation study, the sub-dimensions were revised by decreasing the number of items as follows; gross motor skills - 36 items, fine motor skills - 23 items, preparation for literacy skills - 26 items, cognitive skills - 68 items, language skills - 48 items, self-care skills - 29 items, personal/social development skills 26 items. Internal consistency coefficients were between .91 to .98 for the whole scale, whereas they were found to vary between .70 and .97 (language development) for its sub-dimensions. The test-retest coefficients of the original scale were .96 and .99 , whereas the test-retest coefficients of the adaptation study were .93 and .99. The Language Development subtest used in this study includes the receptive language (understanding the information provided by various sources such as sounds, words, gestures and gestures-mimics) and expressive language (our thoughts and emotions through words, gesturesmimics and symbols) and phonological awareness skills.

\section{Data Collection}

To collect research data, firstly, the principals and teachers of preschool education institutions, whose school facilities were already known to be suitable for individual testing of children, were visited. In these schools, the purpose of the research and the implementation process was explained and their opinions about their participation in the study were asked. After three preschool education institutions have accepted to participate in the study, the researchers met the children in their classroom under the supervision of their teachers and briefly told them what to do. Researchers carried out the applications related to children's patterning skills and language development in a quiet and bright classroom within the school, while the education process was continuing, by calling the children one by one. Individual applications involving children's skills were carried out by two researchers, the first researcher applied 
patterning skills test, and the second applied language development test. Both applications took about 1520 minutes.

\section{Data Analysis}

SPSS 21 package program was used to analyze the data of the study. Descriptive analysis showed that language development data were not distributed normally; in addition, although patterning skills data were distributed normally, the amount of data falling in the variable categories was less than 30 , therefore the analyzes were performed using non-parametric tests. In the analysis of patterning skills and language development data, U-test was performed to reveal if there is a differentiation in terms of gender, parents' education level and age. In addition, Kruskal Wallis $\mathrm{H}$ analysis was performed to determine whether patterning skills differ according to the frequency of patterning activities. Finally, Spearman correlation analysis was performed to determine the relationship between children's patterning skills and language development.

\section{RESULTS}

Table 1. U-test results of patterning skills and language development scores according to gender

\begin{tabular}{|l|l|l|l|l|l|l|}
\hline & Gender & $\mathbf{N}$ & $\overline{\boldsymbol{x}}$ & $\mathbf{U}$ & $\mathbf{Z}$ & $\mathbf{p}$ \\
\hline \multirow{2}{*}{ Patterning skills } & Female & 39 & 36.05 & 466.00 & -1.020 & \multirow{2}{*}{308} \\
\cline { 2 - 8 } & Male & 28 & 31.14 & & & \\
\hline \multirow{2}{*}{ Language Development } & Female & 39 & 37.12 & 424.50 & -1.548 & \multirow{2}{*}{122} \\
\cline { 2 - 7 } & Male & 28 & 29.66 & & & \\
\hline
\end{tabular}

$p>.05$

As a result of the analysis performed to compare Patterning skills scores ( $U=466.00 ; p>.05)$ and Language Development scores $(U=424.500$; $p>.05)$ of the children in the study group according to the gender, no significant difference was found according to gender.

Table 2. U-test results of patterning skills and language development scores according to mother's and father's education level

\begin{tabular}{|c|c|c|c|c|c|c|c|}
\hline & & Education Level & $\mathbf{N}$ & $\bar{x}$ & $\mathbf{U}$ & $\mathbf{Z}$ & $\mathbf{p}$ \\
\hline \multirow{4}{*}{ 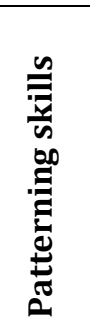 } & \multirow{2}{*}{ Mother's Education Level } & $\begin{array}{lll}\text { High school and } \\
\text { below }\end{array}$ & 39 & 27.79 & \multirow{2}{*}{304.00} & \multirow{2}{*}{-2.910} & \multirow{2}{*}{$.004^{*}$} \\
\hline & & $\begin{array}{l}\text { Associate degree and } \\
\text { above }\end{array}$ & 27 & 41.74 & & & \\
\hline & \multirow{2}{*}{ Father's Education Level } & $\begin{array}{lll}\begin{array}{l}\text { High school and } \\
\text { below }\end{array} & \\
\end{array}$ & 38 & 28.61 & \multirow{2}{*}{346.00} & \multirow{2}{*}{-2.230} & \multirow{2}{*}{$.026^{*}$} \\
\hline & & $\begin{array}{l}\text { Associate degree and } \\
\text { above }\end{array}$ & 27 & 39.19 & & & \\
\hline \multirow{4}{*}{ 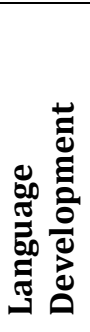 } & \multirow{2}{*}{ Mother's Education Level } & \begin{tabular}{|lll} 
High school and \\
below
\end{tabular} & 39 & 27.81 & \multirow{2}{*}{304.50} & \multirow{2}{*}{-2.902} & \multirow{2}{*}{$.004^{*}$} \\
\hline & & $\begin{array}{l}\text { Associate degree and } \\
\text { above }\end{array}$ & 27 & 41.72 & & & \\
\hline & \multirow{2}{*}{ Father's Education Level } & \begin{tabular}{|lll}
$\begin{array}{l}\text { High school and } \\
\text { below }\end{array}$ & \\
\end{tabular} & 38 & 27.45 & \multirow{2}{*}{302.00} & \multirow{2}{*}{-2.815} & \multirow{2}{*}{$.005^{*}$} \\
\hline & & $\begin{array}{l}\text { Associate degree and } \\
\text { above }\end{array}$ & 27 & 40.81 & & & \\
\hline
\end{tabular}

As a result of the analysis, children's Patterning skills scores were observed to differ significantly according to mother's education $(U=304.000 ; p<.05)$ and father's education $(U=346.000 ; p<.05)$, in favor of mothers and fathers having an associate degree or above. Again, children's Language Development scores showed a significant difference according to the mother's education $(U=304,500 ; p$ $<.05$ ) and father's education level ( $\mathrm{U}=302.00$; $\mathrm{p}<.05)$, in favor of mothers and fathers having an associate degree or above. 
Table 3. U-test results of patterning skills and language development scores according to age range

\begin{tabular}{|c|c|c|c|c|c|c|}
\hline & Age & $\mathbf{N}$ & $\bar{x}$ & U & Z & p \\
\hline \multirow{2}{*}{ Patterning skills } & 58-67-month-old & 38 & 27.28 & \multirow{2}{*}{295.50} & \multirow{2}{*}{-3.243} & \multirow{2}{*}{$.001^{*}$} \\
\hline & 68-77-month-old & 29 & 42.81 & & & \\
\hline Language & 58-67-month-old & 38 & 28.99 & \multirow{2}{*}{360.500} & \multirow{2}{*}{-2.416} & \multirow{2}{*}{$.016^{*}$} \\
\hline Development & 68-77-month-old & 29 & 40.57 & & & \\
\hline
\end{tabular}

$p<.05$

As a result of the analysis performed to compare Patterning skills scores $(U=295.50 ; p>.05)$ and Language Development scores ( $U=360.500 ; \mathrm{p}>.05)$ of the children in the study group according to age, a significant difference was observed in favor of 68-77-month-old children.

Table 4. U-test results of patterning skills scores according to patterning frequency

\begin{tabular}{|l|l|l|l|l|l|}
\hline Patterning Frequency & $\mathbf{N}$ & $\overline{\boldsymbol{x}}$ & $\mathbf{U}$ & $\mathbf{Z}$ & $\mathbf{p}$ \\
\hline Less than once a week & 41 & 29.85 & \multirow{2}{*}{363.000} & -2.194 & $.028^{*}$ \\
\hline More than once a week & 26 & 40.54 & & & .0 \\
\hline
\end{tabular}
$p<.05$

As a result of the $U$ test performed to compare patterning skill scores of the children in the study group according to the frequency of patterning activities, a significant difference was observed in favor of those who do more than one activity per week $(\mathrm{U}=363.00 ; \mathrm{p}<.05)$.

Table 5. Results of spearman correlation analysis performed to determine the relationship between "lap-3 development assessment scale/language development sub-dimension" and "patterning skills scale" scores

\begin{tabular}{|l|l|l|l|}
\hline & $\mathbf{N}$ & $\mathbf{r}$ & $\mathbf{p}$ \\
\hline $\begin{array}{l}\text { Patterning skills }- \\
\text { Language } \\
\text { Development }\end{array}$ & 67 & .446 & $.000^{* *}$ \\
\hline${ }^{* *} p<0.01$ & & \\
\hline
\end{tabular}

As a result of the Spearman correlation analysis performed to determine the relationship between patterning skills scores and Language Development scores of the children in the study group, a moderate positive correlation (Durmuş, Yurtkoru, \& Zinc, 2018) was found ( $r=, 446 ; p<0.01$ ). This shows that children's patterning skills scores increase as their language development scores increase.

\section{DISCUSSION AND CONCLUSIONS}

As a result of the study, it was found that gender did not create a significant difference in the patterning skills and language skills of the participating children. Kesicioglu (2013) also reached the result that gender does not create a significant difference in patterning skills. Similarly, in some studies involving language development, gender did not create a significant difference on language development, which is in line with the results of our study (Ergin, 2012; Ylldırım, 2008), but there are also results showing that gender makes a significant difference on language development in favor of girls (Eryllmaz, Uardı, Geyik, \& Öztürk, 2019; Stolt, Haataja, Lapinleium, \& Lehtonen, 2008) and boys (Koçak, Ergin, \& Yalçın, 2014). Differences in Language Development according to gender is explained by the ability and early age. It has been reported that this difference does not exist in later ages. Similarly, it is thought that since the preschool period is a period of rapid development, the impact of individual differences causes differences in the research results (Penn, 2008; Fox, \& Field, 1989). Therefore, to determine the cause of the differentiation in patterning and language development, they should be tested in more samples.

Another finding obtained from the research is that significant differences were observed on patterning skills and language development according to parents' education levels, in favor of those having an associate degree or above. Based on these findings, it can be said that the education levels of parents affect patterning skills and language development scores. Regarding the studies on mathematics skills and parents' education level in the literature, results are indicating that the education level of the parents creates a significant difference on mathematics skills (Kodippili, 2011; Güven, 1997). This also supports the findings of our research involving patterning skills, which is the basis of mathematics. 
Similarly, the review of the studies on language development and parents' education level also showed that the results are in line with the results of our study (Koçak et al., 2014; Yıldırım 2008; Hoff 2003). The findings obtained from the studies show that the education levels of the parents are effective on patterning and language development, which suggests that as the education level of the parents increases, their awareness also increase and thus they can approach child-rearing processes more consciously. In the study the number of parents having an education below and above associate degree was not equal, therefore it may be healthier to conduct the study once more with different samples.

The analysis of children's patterning skills according to age revealed a significant difference in favor of older children (68-77-month-old). Based on this finding, it can be said that the age group affects patterning skill scores. Regarding the studies on patterning skills according to age group in the literature, results are indicating that the age group makes a significant difference on patterning skills (Fyfe, McNeil, \& Rittle-Johnson, 2015), which are in line with the results of our study; on the other hand, there are also results indicating that the age group does not create a significant difference on patterning skills (Kesicioğlu, 2013). Regarding the studies on language development according to age group, findings are showing that age group creates a significant difference on language development in favor of the older age group, which is in parallel with the results of our study, (Koçak et al, 2014; Ergin, 2012; Ylldırım 2008; Aksu-Koç, \& Ketrez, 2016). This is an expected result of the development process.

In the study, it was found that patterning skill scores showed a significant difference according to the frequency of patterning activities included in the education process in favor of more frequent patterning activities. Based on this finding, it can be said that the frequency of patterning activities in the educational setting affects patterning skill scores. Researchers believe that the inclusion of patterning activities in preschool settings makes a difference in patterning skills (Clements, Sarama, \& Liu, 2008; Papic et al., 2011; Starkey, Klein, \& Wakeley, 2004). In the experimental studies on the development of patterning skills in the literature, the experimental group were found to get better results than the control group (Papic, \& Mulligan, 2007; Papic, \& Mulligan, 2005). These results overlap with the results of our study and show that the systematic and frequent use of patterning activities affects the development of these skills.

The finding obtained from the research shows a positive moderate association between patterning skills and language development. Based on this, it can be said that as the patterning skills of children increase, their language development increases. Regarding the literature, although few studies are focusing on language development and patterning skills, the studies addressing mathematics skills and language development support this finding of our research (Abedi, \& Lord, 2001; McClelland, Cameron, Connor, Farris, Jewkes, \& Morrison, 2007; Miller, Müller, Giesbrecht, Carpendale, \& Kerns, 2013; Taşkın, 2013).

In future studies, relationships between preschool children's patterning skills and skills such as reasoning and creative thinking can be examined. The factors that affect these skills can be tested with experimental studies. The relationship between these two skills and children's school achievement can be investigated through longitudinal studies. Similar studies can be extended to children with bilingual development. In addition to these, the further contribution can be made to the literature by diversifying variables (such as socio-economic level, education program, age, parents' mathematics knowledge, mathematics at the home setting).

Finally, this study was carried out with 67 children aged between 58-77 months. Studies on Language Development and patterning skills with younger and older age groups can be conducted and the results can be compared. Other researches to be conducted in line with the purposes of this study can be formed to cover different provinces and more study groups.

\section{REFERENCES}

Abedi, J., \& Lord, C. (2001). The language factor in mathematics tests. Applied Measurement in Education, 14(3), 219-234. doi: 10.1207/S15324818AME1403_2

Aksu Koç, A., \& Ketrez, F. (2016). Anadili gelişimi. In Ç. Aydın, T. Göksun, A. C. Küntay, \& D. Tahiroğlu, Aklın çocuk hali zihin gelişimi araştırmaları (pp. 13-41). İstanbul: Koç Üniversitesi Yayınları.

Armstrong, D. F. (1983). Iconicity, arbitrariness \& duality of patterning in signed \& spoken language: Perspectives on language evolution. Sign Language Studies, 1038(1), 51-83. doi:10.1353/sls.1983.0013

Arslan, A. (2013). Okuma becerisi ile ilgili makalelerde cinsiyet değişkeni. Uluslararası Türkçe Edebiyat Kültür Eğitim Dergisi. 2(2), 251-265.

Austin, J. L., \& Howson, A. G. (1979). Language and mathematical education. Educational Studies in Mathematics. 10(2),161-197. 
Bauer, L. (2006). Morphology: Overview. In K. Brown (Ed.), Encyclopedia of language \& linguistics (s. 316-318). Oxford: Elsevier.

Berwick, R. C., \& Chomsky, N. (2011). The biolinguistic program: The current state of its development. In A. M. Di Sciullo \& C. Boeckx (Ed), The biolinguistic enterprise: New perspectives on the evolution and nature of the human language faculty (pp. 19-41). Oxford University Press.

Başaran, N. (2006). Erken öğrenme becerileri değerlendirme aracının Tokat örnekleminde 48-66 aylık Türk çocuklarına uyarlanması. Yayınlanmamış yüksek lisans tezi, Gazi Üniversitesi, Eğitim Bilimleri Enstitüsü, Ankara.

Burgoyne, K., Witteveen, K., Tolan, A., Malone, S., \& Hulme, C. (2017). Pattern understanding: Relationships with arithmetic and reading development. Child Development Perspectives, 11(4), 239-244. doi:10.1111/cdep.12240

Büyüköztürk, Ş., Kılıç Çakmak, E., Akgün, Ö. E., Karadeniz, Ş., \& Demirel, F. (2017). Bilimsel araştırma yöntemleri. Ankara: PEGEM Akademi Yayıncılık.

Charlesworth, R., \& Lind, K.K. (2007). Math \& Science for young children. (5. Baskı). New York: Thomson Delmar learning.

Chater, N., \& Christiansen, M. H. (2010). Language acquisition meets language evolution. Cognitive Science, 34(7), 1131-1157. doi:10.1111/j.1551-6709.2009.01049.x

Christiansen, M. H., \& Chater. (2008). Language as shaped by the brain. Behav Brain Sci, 31(5), 489-508. doi:10.1017/S0140525X08004998

Christiansen, M. H., Chater, N., \& Reali, F. (2009). The biological and cultural foundations of language. Communicative \& Integrative Biology, 2(3), 221-222. doi:10.4161/cib.2.3.8034

Clements, D. H., Sarama, J. H., \& Liu, X. H. (2008). Development of a measure of early mathematics achievement using the Rasch model: The research-based early maths assessment. Educational Psychology, 28, 457-482. doi:10.1080=01443410701777272

Collins, M. A., \& Laski, E. V. (2015). Preschoolers' strategies for solving visual pattern tasks. Early Childhood Research Quarterly, 32, 204-214. doi:10.1016/j.ecresq.2015.04.004

Cowan, R., Donlan, C., Newton, E. J., \& Lloyd, D. (2005). Number skills and knowledge in children with specific language impairment. Journal of Educational Psychology, 97(4), 732-744.

Dehaene, S.,Piazza, M.,Pinel, P.,\& \& Cohen, I. (2003). Three parietal circuits for number processing. Cognitive Neuropsychology, 20, 487-506. doi: 10.1080/02643290244000239

Dinçer, Ç., \& Ergül, A. (2017). Eşleştirme, gruplama/sınıflama, karşılaştırma, sıralama ve örüntü. In İ. Ulutaş. (Ed.). Okul öncesinde matematik eğitimi. (4. Baskı). Ankara: Hedef CS Basın Yayın

Donlan, C., Cowan, R., Newton, E. J., \& Lloyd, D. (2007). The role of language in mathematical development: Evidence from children with specific language impairments. Cognition, 103, 23-33. doi: 10.1016/j.cognition.2006.02.007

Durmuş, B., Yurtkoru, E. S., \& Çinko, M. (2018). Sosyal bilimlerde SPSS'le veri analizi. İstanbul: Beta.

Ergin, B. (2012). 5-6 yaş çocuklarının dil gelişim düzeyleri ile sosyal kabul durumları arasındaki ilişskinin incelenmesi. Yayınlanmamış yüksek lisans tezi, Selçuk Üniversitesi, Sosyal Bilimler Enstitüsü, Konya.

Eryılmaz, D., Uladı, G., Geyik, M., \& Öztürk, M. (2019). 36-72 aylık çocukların dil gelişim özelliklerinin çeşitli değişkenler bakımından incelenmesi. Karabük Üniversitesi Sosyal Bilimler Enstitüsü Dergisi, 9(1), 265-277.

Fazio, B. B. (1994). The counting abilities of children with specific language impairment. Journal of Speech, Language, and Hearing Research, 37(2), 358-368. doi: 10.1044/jshr.3702.358

Fine, J. (1978). Conversation, cohesive and thematic patterning in children's dialogues. Discourse Processes, 1(3), 247-266. doi: 10.1080/01638537809544439

Fox, N. A., \& Field, T. M. (1989). Individual differences in preschool entry behavior. Journal of Applied Developmental Psychology, 10(4), 527-540.

Fyfe, E. R., Eisenband Matz, L., Hunt, K. M., \& Alibali, M. W. (2018). Mathematical thinking in children with developmental language disorder: The roles of pattern skills and verbal working memory. Journal of Communication Disorders, 77, 17-30. doi:10.1016/j.jcomdis.2018.11.001

Fyfe, E., McNeil, N., \& Rittle-Johnson, B. (2015). Easy as ABCABC: Abstract language ficilitates performance on a concrete patterning task. Child Development, 86(3), 927-935. doi:10.1111/cdev.12331

Fyfe, E.R., Evans J.L., Eisenband Matz, L. Hunt, K.M., \& Alibali, M. W. (2017). Relations between patterning skill and differing aspects of early mathematics knowledge. Cognitive Development, 44, 1-11. doi: 10.1016/j.cogdev.2017.07.003

Gelman, R., \& Buterworth, B. (2005). Number and Language: How are they related?. Trends in Cognitive Sciences, 9(1), 6-10. doi: 10.1016/j.tics.2004.11.004 
Grandau, L. (2015). You Have to Speak, Listen, Read, and Write to Teach and Learn Math. Annenberg Learner, Teacher resources and professional development across the curriculum. https://learnerlog.org/author/laura-grandau/

Green, K. B., Peggy A. (2014). Mathematics for young children: a review of the literature with implications for children with disabilities. Başkent University Journal of Education, 1(1), 81-92.

Güven, Y. (1997). Erken Matematik Yeteneği Testi-2'nin geçerlik, güvenirlik, norm çalışması ve sosyokültürel faktörlerin matematik yeteneğine etkisinin incelenmesi. Yayınlanmamış doktora tezi, Marmara Üniversitesi, Sosyal Bilimler Enstitüsü, İstanbul.

Güven, Y. (2005). Erken çocuklukta matematiksel düşünme ve matematiği öğrenme. İstanbul: Küçük Adımlar Eğitim Yayınları.

Güven, Y., Dibek, E., Bayındır, D., \& Saçkes, M. (2019). Okul öncesi örüntü becerileri testinin geliștirilmesi: Geçerlilik ve güvenilirlik çalışması. Necatibey Eğitim Fakültesi Elektronik Fen ve Matematik Eğitimi Dergisi, 13(2), 545-563. doi: balikesirnef.588966

Haciibrahimoğlu, Y..B. (2015). Örüntü ve fonksiyon. In B.Akman (Ed.). Okul Öncesi matematik eğitimi (s.121-122). Ankara: Pegem Akademi

Herschensohn, J. (2007). Language development and age. Cambridge: Cambridge University Press.

Hoff, E. (2003). Causes and consequences of SES-related differences in parent-to-child speech. In M. H. Bornstein \& R. H. Bradley (Eds.), Monographs in parenting series. Socioeconomic status, parenting, and child development (pp. 147-160). Lawrence Erlbaum Associates Publishers.

Hooper, S. R., Roberts, J., Sideris, J., Burchinal, M., \& Zeisel, S. (2010). Longitudinal predictors of reading and math trajectories through middle school for African American versus Caucasian students across two samples. Developmental Psychology, 46(5), 1018-1029. doi: 10.1037/a0018877.

İmer, K., Kocaman, A., \& Özsoy, A. S. (2011). Dilbilim sözlüğü. İstanbul: Boğaziçi Üniversitesi Yayınları.

Kesicioğlu, O. S. (2013). Okul öncesi dönem çocuklarının matematiksel örüntü becerilerinin incelenmesi. Akdeniz Eğitim Araştırmaları Dergisi, 7(13),19-26.

Klein, A., \& Starkey, P. (2004). Fostering preschool children's mathematical knowledge: Findings from the Berkeley Math Readiness Project. In D. H. Clements, J. Sarama, \& A. M. DiBiase (Ed.), Engaging young children in mathematics (pp. 343-360). Mahwah, NJ: Erlbaum.

Koçak, N., Ergin, B., \& Yalçın, H. (2014). 60-72 aylık çocukların Türkçe dil kullanımı düzeyleri ve etki eden faktörlerin incelenmesi. KMÜ Sosyal ve Ekonomik Araştırmalar Dergisi,11, 100-106.

Kodippili, A. (2011). Parents' education level in students' mathematics achievement; do school factors matter? Academic Leadership: The Online Journal, 9(1), 1-11.

Korkmaz, B. (2005). Dil ve beyin: Çocuklarda dil ve konuşma bozuklukları. İstanbul: Yüce Yayım.

Lee, K., Ng, S. F., Bull, R., Pe, M. L., \& Ho, R. (2011). Are patterns important? An investigation of the relationships between proficiencies in patterns, computation, executive functioning and algebraic word problems. Journal of Educational Psychology, 103, 269-281. doi: 10.1037/a0023068

Lee, K., Ng, S. F., Pe, M. L., Ang, S. Y., Hasshim, M., \& Bull, R. (2012). The cognitive underpinnings of emerging mathematical skills: Executive functioning, patterns, numeracy and arithmetic. British Journal of Educational Psychology, 82, 82-99. doi: 10.1111/j.2044-8279.2010.02016.x

Lovas, G. S. (2010). Gender and patterns of language development in mother-toddler and father-toddler dyads. First Language, 31(1), 83-108. doi:10.1177/0142723709359241

McClelland M. M., Cameron C. E., Connor C. M., Farris C. L., Jewkes A. M, Morrison F. J. (2007). Links between behavioral regulation and preschoolers' literacy, vocabulary, and math skills. Developmental Psychology. 43(4), 947-959. doi:10.1037/0012-1649.43.4.947

Mey, J. L. (2006). Pragmatics: Overview. In K. Brown (Ed.), Encyclopedia of language \& linguistics (s. 5162). Oxford: Elsevier.

Miller, M., Müller, U., Giesbrecht, G. F., Carpendale, J., \& Kerns, K. (2013). The contribution of executive function and social understanding to preschoolers' letter and math skills. Cognitive Development, 28(4), 331-349. doi:10.1016/j.cogdev.2012.10.005

Moses, R. P., \& Cobb, C. E. (2001). Radical equations: Math literacy and civil rights. Boston: Beacon Press.

Muslugüme, E. (2015). Dil gelişimi destekleyici ebeveyn eğitim programının sosyo ekonomik düzeyi düşük ailelerin çocuklarının dil gelişimine etkisi. Yayınlanmamış yüksek lisans tezi, Pamukkale Üniversitesi, Eğitim Bilimleri Enstitüsü, Denizli.

NCCA. (2014). Mathematics in early childhood and primary education (3-8 years). Dublin: National Council of Curriculum and Assessment.

NCTM. (2006). Curriculum focal points for prekindergarten through grade 8 mathematics. Reston, VA: National Council of Teachers of Mathematics.

Nelson, K. (1996). Language in cognitive development: The emergence of the mediated mind. Cambridge University Press. 
Nettle, D. (1998). Explaining Global Patterns of Language Diversity. Journal of Anthropological Archaeology, 17(4), 354-374. doi: 10.1006/jaar.1998.0328

Özdemir, E. (2013). İlköğretim 6. 7., \& 8. sınıf öğrencilerinin matematiksel örüntüleri kavrayabilme ve genelleyebilme süreçleri. Yayınlanmamış doktora tezi, Atatürk Üniversitesi, Eğitim Bilimleri Enstitüsü, Erzurum.

Papic, M. M., \& Mulligan, J. T. (2005). Pre-schoolers' mathematical patterning. In P. Clarkson, A. Downton, D. Gronn, M. Horne, A. McDobough, R. Pierce, \& A. Roche (Ed.), Building connections: Research, theory, and practice. Proceedings of the 28th annual conference of the Mathematical Education Research Group of Australasia (pp. 609-616). Sydney: MERGA

Papic, M. M., \& Mulligan, J. T. (2007). The growth of early mathematical patterning: An intervention study. In J. Watson, \& K. Beswick (Eds.),Mathematics: Essential research, essential practice (Proceedings of the 30th annual conference of the Mathematics Education Research Group of Australasia, Hobart, Vol. 2, pp. 591-600). Adelaide: MERGA.

Papic, M. M., Mulligan, J. T., \& Mitchelmore, M. C. (2011). Assessing the development of preschoolers' mathematical patterning. Journal for Research in Mathematics Education, 42, 237-268. doi: 10.5951/jresematheduc.42.3.0237

Pasnak, R., Kidd, J., Gadzichowski, M., Gallington, D. A., Schmerold, K. L., Schmerold, K. L., \& West, H. (2015). Abstracting sequences: Reasoning that is a key to academic achievement. The Journal of Genetic Psychology, 176, 171-193. doi: 10.1080/00221325.2015.1024198

Penn, H. (2008). Understanding early childhood. Open University Press.

Pinker, S. (1999). Words and rules: The ingredients of language. New York: Basic Books.

Purpura, D. J., \& Ganley, C. M. (2014). Working memory and language: Skill-specific or domain-general relations to mathematics? Journal of Experimental Child Psychology, 122, 104-121.

Purpura, D.J.,Lume,L., Sims,D., \& Lonigan, C.J. (2011). Early literacy and early numeracy: The value of including early literacy skills in te prediction of numeracy development. Journal of Experimental Child Psychology, 110, 647-658. doi: 10.1016/j.jecp.2013.12.009

Ravignani, A. (2014). The evolutionary origins of rhythm: A top-down/bottom-up approach to temporal patterning in music and language. Procedia Social and Behavioral Sciences, 126, 113-114. doi: 10.1016/j.sbspro.2014.02.334

Resnik, M. D. (1982). Mathematics as a science of patterns: Epistemology. Nous, 16(1) 95-105.

Rittle-Johnson, B., Fyfe, E. R., Hofer, K. G., \& Farran, D. C. (2016). Early math trajectories: low-income children's mathematics knowledge from ages 4 to 11. Child Development, 88(5), 1727-1742. doi: 10.1111/cdev.12662

Rittle-Johnson, B., Fyfe, E. R., McLean, L. E., \& McEldoon, K. L. (2013). Emerging understanding of patterning in 4-year-olds. Journal of Cognition and Development, 14(3), 376-396. doi:10.1080/15248372.2012.689897

Rittle-Johnson, B., Singer,R.S., \& Alibali, M.W. (2001). Developing Conceptual Understanding and Procedural Skill in Mathematics: An Iterative Process. Journal of Educational Psychology, 93 (2), 346-362

Rittle-Johnson, B., Zippert, E. L., \& Boice, K. L. (2018). The roles of patterning and spatial skills in early mathematics development. Early Childhood Research Quarterly, 46(1), 1-13. doi: 10.1016/j.ecresq.2018.03.006

Sacks, H., Schegloff, E. A., Jefferson, G. A. (1974). A simplest systematics for the organization of turntaking for conversation. Language, 50, 696-735. doi:10.1016/b978-0-12-623550-0.50008-2

Saeed, J. L. (2001). Semantics. In N. J. Smelserve P. B. Baltes (Ed.), International encyclopedia of the social \& behavioral sciences (pp. 13881-13997). Elsevier.

Sandra, L. (2019). Introduction to language development. San Diago: Plural Publishing Inc.

Sapir, E. (1925). Sound patterns in language. Linguistic Society of America. 1(2), 37-51. doi: $10.2307 / 409004$

Starkey, P., Klein, A., \& Wakeley, A. (2004). Enhancing young children's mathematical knowledge through a pre-kindergarten mathematics intervention. Early Childhood Research Quarterly, 19, 99-120. doi: 10.1016=j.ecresq.2004.01.002

Steen, L. A. (1988). The science of patterns. Science, 240(4852), 611-616. doi: 10.1126/science.240.4852.611

Stolt, S., Haataja, L., Lapinleium, H., \& Lehtonen, L. (2008). Early lexical development of Finnish children: A longitudinal study. First Language, 28, 259-279. doi: 10.1177/0142723708091051

Taner, M., \& Başal, H. A. (2005). Farklı sosyoekonomik düzeylerde okul öncesi eğitimi alan ve almayan ilköğretim birinci sınıf öğrencilerinin dil gelişimlerinin cinsiyete göre karşılaştırılması. Uludağ Üniversitesi Eğitim Fakültesi Dergisi, 18(2), 395-420. 
Taşkın, N. (2013). Okul öncesi dönemde matematik ile dil arasındaki ilişki üzerine bir inceleme. Yayınlanmamış doktora tezi, Hacettepe Üniversitesi, Sosyal Bilimler Enstitüsü, Ankara.

Tirosh, D., Tsamir, P., Barkai, R., \& Levenson, E. (2018). Engaging young children with mathematical activities involving different representations: triangles, patterns and counting objects. CEPS Journal, 8(2), 9-30 doi: 10.26529/cepsj.271

Toll, S. W. M., \& Van Luit, J. E. H. (2014). The Developmental Relationship Between Language and Low Early Numeracy Skills Throughout Kindergarten. Exceptional Children, 81(1), 64-78.

Tunçeli, H. İ. (2017). LAP-3 gelişim değerlendirme ölçeği'nin türkçe'ye uyarlanması ve $48-72$ aylık çocukların gelişimlerinin incelenmesi. Yayınlanmamış doktora tezi, Marmara Üniversitesi, Eğitim Bilimleri Enstitüsü, İstanbul.

Vanderheyden, A. M., Broussard, C., Snyder, P., George, J., Meche Lafleur, S., \& Williams, C. (2011). Measurement of kindergartners' understanding of early mathematical concepts. School Psychology Review, 40, 296-306.

Vinner, S. (2014). Concept development in mathematics education. In S. Lerman (Ed.), Encyclopedia of mathematics education. Springer, Dordrecht. doi: 10.1007/978-94-007-4978-8_29

Vukovic, R. K., \& Lesaux, N. K. (2013). The language of mathematics: Investigating the ways language counts for children's mathematical development. Journal of Experimental Child Psychology, 115, 227-244. doi: 10.1016/j.jecp.2013.02.002

Wiese, R. (2006). Phonology: Overview. In K. Brown (Ed.), Encyclopedia of language \& linguistics (pp. 562-564). Oxford: Elsevier.

Warren, E., \& Cooper, T. (2006). Using repeating patterns to explore functional thinking. Australian Primary Mathematics Classroom, 11, 9-14.

Welkowitz, J., Bond, R. N., Feldman, L., \& Tota, M. E. (1990). Conversational time patterns and mutual influence in parent-child interactions: A time series approach. Journal of Psycholinguistic Research, 19(4), 221-243. doi:10.1007/bf01077258

Yaman, H., \& Umay, A. (2013). The elementary students' perceptions of mathematical patterns according to presentation forms. H.U. Journal of Education, 28(1), 405-416.

Yapıcı, Ş. (2004). Çocukta dil gelişimi. İnsan Bilimleri Dergisi, 1(1), 1-17.

Yeşildere, S., \& Akkoç, H. (2010). Matematik öğretmen adaylarının sayı örüntülerine ilişkin pedagojik alan bilgilerinin konuya özel stratejiler bağlamında incelenmesi. Ondokuz Mayıs Üniversitesi Eğitim Fakültesi Dergisi, 29(1), 125-149.

Yıldırım Hacıibrahimoğlu, B. (2019). In Örüntü ve fonksiyon. B. Akman (Ed.), Erken çocuklukta matematik eğitimi (pp. 113-122). Ankara: Pegem Akademi.

Yıldırım, A. (2008). Okul öncesi eğitim kurumlarından yararlanmayan 4-5 yaş çocuklarının dil gelişimini etkileyen faktörlerin incelenmesi (Konya ili örneği). Yayınlanmamış yüksek lisans tezi, Selçuk Üniversitesi, Sosyal Bilimler Enstitüsü, Konya. 